\title{
FLOW ANALYSIS AND MODELING OF THE LAKE ÁGUA PRETA: WATER SOURCE OF THE BELÉM METROPOLITAN AREA
}

\footnotetext{
P. S. Holanda ${ }^{a}$, C. J. C. Blancob, D. O. A.Cruz D. F. Lopes ${ }^{a}$, A. R. B. Barp ${ }^{b}$, and Y. Secretan ${ }^{d}$

${ }^{\mathrm{a}}$ Universidade Federal do Pará

Estudante de Doutorado PRODERNA/ITEC/UFPA

Rua Augusto Côrrea, 01 Bairro Guamá CP. 66075-110, Belém, Pará, Brasil pholanda@ufpa.br davi.lopes@cprm.gov.br ${ }^{\mathrm{b}}$ Universidade Federal do Pará Professor da Faculdade de Engenharia Sanitária e Ambiental FAESA/ITEC/UFPA

Rua Augusto Corrêa, 01

Bairro Guamá

CP. 66075-110, Belém, Pará, Brasil blanco@ufpa.br anabarp@ufpa.br

${ }^{\mathrm{c}}$ Universidade Federal do Pará Professor da Faculdade de Engenharia Mecânica FEM/ITEC/UFPA Rua Augusto Corrêa, 01 Bairro Guamá CP. 66075-110, Belém, Pará, Brasil doac@ufpa.br ${ }^{\mathrm{d}}$ INRS-ETE - Institut National de la Recherche Scientifique G1K 9A9, Québec (Qc), CANADA

Yves.Secretan@ete.inrs.ca
}

\section{ABSTRACT}

The natural conditions of water resources can be modified with the unsustainable use of them. For example, in Belém, capital of Pará State, Água Preta Lake has a history of degradation jeopardize the drinking water supply in Belém. Thus, the main contribution of this work is to develop a study on modeling hydrodynamic study of Água Preta Lake. Such study is carried through the bathymetric of 2009 performed with an ADCP. The bathymetry and substrate data that composes the Lake and its boundary. The bathymetry data are used to construct the digital elevation model, with the coordinates $\mathrm{x}, \mathrm{y}$ and $\mathrm{z}$ in UTM; while the composition of the substrate is used for the determination of the Manning coefficient. The coordinates $\mathrm{x}, \mathrm{y}$, $\mathrm{z}$ and Manning coefficient are used in the hydrodynamic model. This one is the classic model of Saint-Venant. In this case, a vertical integration is applied to the three-dimensional equations of Navier-Stokes for incompressible flow with outline conditions, of bottom and of liquid and solid surface, included. Thus, the problem becomes two-dimensional (2D) and the values obtained for velocities are medium in the vertical direction. The velocities are the input data for the many models, such as pollutant dispersion sediment transport and aquatic fauna and flora habitats. Thus, besides of hydrodynamic model explains the patterns of flow in the lake, it can be employed for the others models of the Lake Água Preta.

Keywords: digital elevation, hydrodynamic modeling, Água Preta.

\section{NOMENCLATURE}

ADCP Acoustic Doppler Current Profile D deformation tensor component, $\mathrm{N} / \mathrm{m}^{2}$ $\mathrm{d}_{\text {med }}$ mean, diameter, $\mathrm{mm}$

$\mathrm{F} \quad$ volume force, $\mathrm{N}$

$\mathrm{g}$ acceleration of gravity, $\mathrm{m} / \mathrm{s}^{2}$

$\mathrm{H}$ depth of the water column, $\mathrm{m}$

$\mathrm{h}$ water level, $\mathrm{m}$
L mixing length, $\mathrm{m}$

$\mathrm{n} \quad$ Manning coefficient, dimensionless

N.A water level, $\mathrm{m}$

Prof depth, m

q specific flow rate, $\mathrm{m}^{2} / \mathrm{s}$

$|\vec{q}| \quad$ module of the specific flow rate, $\mathrm{m}^{2} / \mathrm{s}$

TEM Terrain Elevation Model

Topo terrain topography, $\mathrm{m}$ 
$\mathrm{t}$ time, $\mathrm{s}$

$\mathrm{U}$ velocity relative to direction $\mathrm{x}, \mathrm{m} / \mathrm{s}$

$\mathrm{V}$ velocity relative to direction $\mathrm{y}, \mathrm{m} / \mathrm{s}$

$\mathrm{x}$ direction $\mathrm{x}$ of the Cartesian Coordinate System

$\mathrm{y}$ direction $\mathrm{y}$ of the Cartesian Coordinate System

$\mathrm{z} \quad$ direction $\mathrm{z}$ of the Cartesian Coordinate System

\section{Greek symbols}

$\partial \quad$ relative to partial derived

$\rho \quad$ water density, $\mathrm{kg} / \mathrm{m}^{3}$

$\tau \quad$ Reynolds stress tensor, $\mathrm{N} / \mathrm{m}^{2}$

u viscosity, $\mathrm{m}^{2} / \mathrm{s}$

\section{Subscripts}

cx relative to coriolis force in $\mathrm{x}$

cy relative to coriolis force in $\mathrm{y}$

$\mathrm{i}$ relative to plan of $\tau$ and to plan of $\mathrm{D}$, and relative to direction of partial derived

$\mathrm{j} \quad$ relative to plan of $\tau$ and to plan of $\mathrm{D}$, and relative to direction of partial derived

$\mathrm{m}$ relative to mixing

$\mathrm{t}$ relative to turbulent

$\mathrm{x}$ relative to direction $\mathrm{x}$

$\mathrm{y}$ relative to direction $\mathrm{y}$

wx relative to wind force in $\mathrm{x}$

wy relative to wind force in $\mathrm{y}$

\section{INTRODUCTION}

In Belém, State of Pará, two artificial lakes are used for supplying water to the metropolitan area of Belém: Água Preta $\left(3.12 \mathrm{~km}^{2}\right)$ and Bolonha $\left(0.58 \mathrm{~km}^{2}\right)$. These water reservoirs are interconnected and together make up the Utinga water source (Fig. 1).

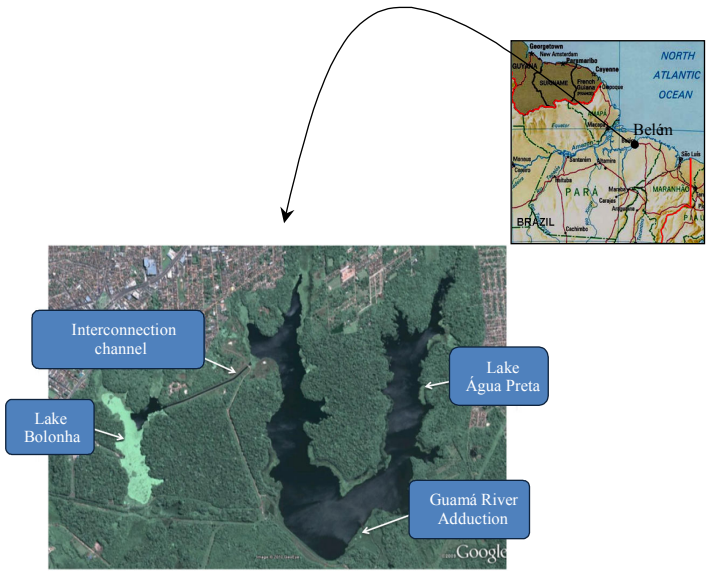

Figure 1. Belém location and satellite picture of Lakes Água Preta and Bolonha. Source: Google Earth, 2009.

The hydro system of the Lakes Água Preta and Bolonha has experienced several environmental aggressions, whether through the constant encroachment, urban sprawl, and land clearing taking place on the heads of the lakes. This raises major concerns with the amount of pollutants that can be added from the houses surrounding these water bodies. The population living in such surrounding area usually does not have proper disposal resources for their sewage, thus causing such wastes to be disposed of near the lakes and hampering the use of the lakes for other purposes such as water supply. Based upon that assumption, the objectives of this paper include the development of a hydrodynamic model for Lake Água Preta that may subsidize studies on the dispersion of pollutants and measure lake management.

\section{METHODOLOGY}

The development of hydrodynamic modeling primarily requires obtaining substrate and topobathymetric data. The topobathymetric data are used for assembly the Terrain Elevation Model (TEM), whereas the substrate composition data are used for setting the Manning coefficient. The TEM plus the roughness model and boundary conditions provided the date for the Saint-Venant equations that were solved, thus allowing for simulating the velocities and depths of Lake Água Preta.

\section{NUMERICAL TOOLS}

In this analysis, the Modeleur and Hydrosim software have been used. These were developed at INRS-ETE, a research center of Université du Québec, Canada (Secretan and Leclerc, 1998; Secretan et al., 2000; Heniche et al., 2000). Modeleur is a combination of a Geographic Information System (G.I.S.) and a powerful Finite Element pre- and postprocessor. It allows for the creation of Terrain Digital Model with information concerning topography, riverbed substrate, wind, ice, and aquatic plants. The Modeleur also enables the division of the analyzed region into partitions. Data sets are associated to the partitions. An automatic procedure of data treatment in the interfaces of the partitions is used for mesh generation of finite elements, which will be used in the solver to resolve the 2-D Saint-Venant model with a drying/wetting capability to follow the shoreline evolution. This solver is called Hydrosim. More details can be obtained in Secretan and Leclerc (1998). Studies conducted by, Blanco et al., (2009), Holanda et al., (2009), Barros et al., (2010) and Holanda et al., (2010) corroborate the efficiency of the model for the region of application, thus allowing the flow simulation and the consequent estimate of velocities.

\section{BATHYMETRIC DATA}

The topobathymetric 2009 was obtained with an $\mathrm{ADCP}$. It has a depht measure range from 100 to 0.30 
$\mathrm{m}$, with a resolution equal to $10.0 \mathrm{~cm}$, adequate for most of the measured depths in the Lake Água Preta. The ADCP sampling frequency equal to $1.00 \mathrm{~Hz}$ allowed a fast data collection with 12.716 topobathymetrics points. Despite the data collection to have been limited due to the environmental conditions of Lake Água Preta, which had considerable amount of macrophytes and tree trunks. Therefore, some areas of (Fig. 2) show the inclusion of 1975 data to address the lack of data from 2009. This insertion did not cause damage to the flow analysis, since in the most dynamic region of the lake, the data are of 2009.

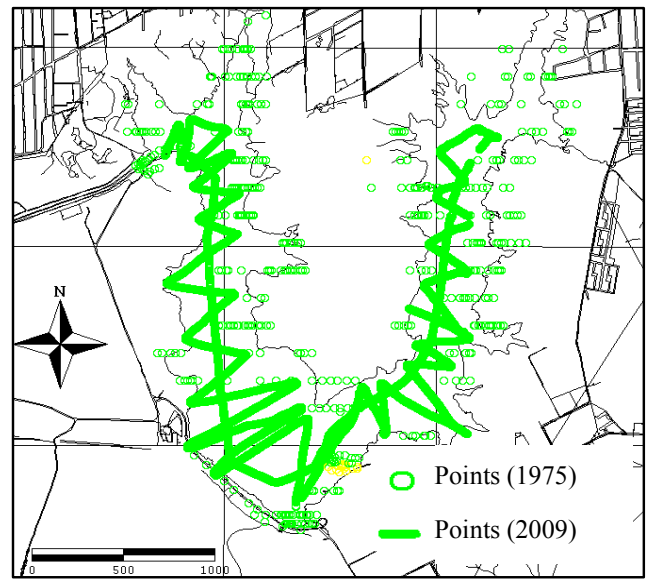

Figure 2. Bathymetric data points.

Figure 3 shows the 2009 TEM's for Lake Água Preta as contour lines from the set of raw. It reveals, as expected, that the region further to the north of lake has greater elevations, since the springs to the creeks making up the lake were located in that region. Such elevations reach up to $15.5 \mathrm{~m}$. Further to the south, the elevations are approximately the same, at $9.5 \mathrm{~m}$, since this is approximately the elevation of the lake's dam crest. The lowest elevations, between $3.5 \mathrm{~m}$ and $4.5 \mathrm{~m}$, are located in the central section of the lake.

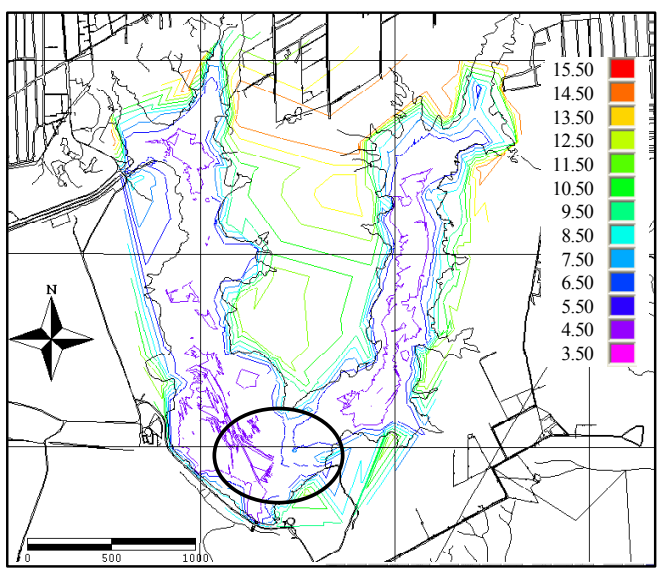

Figure 3. Raw TEM of Lake Água Preta.

\section{LAKE ROUGHNESS MODEL}

The hydrodynamic model needs to include a roughness model. The model used in this paper was determined on the assumption that the lake's substrate is a mean of its granulometry. A reference to such granulometriy can be found in the work of Dias et al., (1991). Table 1 shows the data compiled from their work.

Table 1 - Substrate compostion of Lake Água Preta.

\begin{tabular}{|l|c|c|c|c|}
\hline Particle & \multicolumn{3}{|c|}{ Particle diameter (mm) } & $\%$ \\
\hline Coarse Sand & 2 & to & 0.2 & 47 \\
\hline Fine Sand & 0.2 & to & 0.05 & 33 \\
\hline Silt & 0.05 & to & 0.002 & 8 \\
\hline Clay & \multicolumn{3}{|c|}{0.002} & 12 \\
\hline
\end{tabular}

Considering that the entire bed of the lake is made up by the percentages in Table 1, the Manning friction coefficient $n$ is calculated by the following expression (Secretan et al., 2000),

$$
n=\frac{1}{\left\{34,9\left[-\log \left(d_{\text {med }}\right)\right]^{0.31}\right\}+0,00017}
$$

where the mean diameter of the particles making up the substrate, $d_{\text {med }}$ is equal to $0.7 \mathrm{~mm}$. Thus, the value of $n$ for the bed of Lake Água Preta is equal to 0.019 .

\section{BOUNDARY CONDITIONS}

Another underlying element for formulating the hydrodynamic model includes the appropriate boundary conditions (free surface, bottom and closed, moving or open boundaries), where the values of the input or output flows or properties, in accordance with the boundary typology. The following conditions are considered in this study:

Solid boundaries: imperviousness condition; Liquid boundaries: water levels and outflows.

Figure 4 shows the boundary conditions imposed to Lake Água Preta. Such conditions are for the maximum flows and are explained as follows.

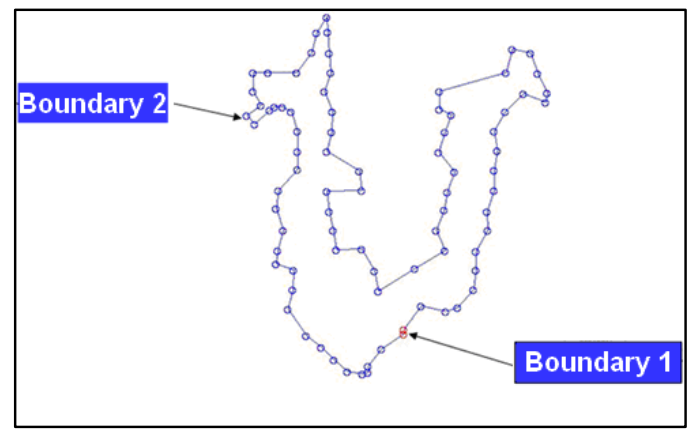

Figure 4. Boundary conditions applied to Lake Água Preta. 
1: Water intake through the adduction of the river Guamá: Flow $=6.0 \mathrm{~m}^{3} / \mathrm{s}$ and water level $=8.9 \mathrm{~m}$.

2: Water outlet through the connecting channel between Lake Bolonha and Lake Água Preta: flow = $6.0 \mathrm{~m}^{3} / \mathrm{s}$ and water level $=8.9 \mathrm{~m}$.

\section{HYDRODYNAMIC MODEL}

A 2-dimensional horizontal hydrodynamic model is adopted. In this case, the mass conservation and momentum equations are integrated with respect to the depth. Thus, the problem becomes twodimensional and the values obtained for the velocities are mean values in the vertical direction. These types of models are referred as Saint-Venant, or shallow waters. The main conditions to be fulfilled for using this model are as follows (Heniche et al., 2000):

- the water column is mixed in the vertical direction and the depth is small in comparison with the width and the length of the water volume;

- the waves are of small amplitude and long period (tide waves). The acceleration's vertical component is negligible, allowing for hydrostatic pressure approximation.

Eqs. (2) - (4) are the conservative form of the Saint-Venant Equations. The first is the continuity equation, whereas the other two are the momentum conservation equations for the fluid, in $x$ and $y$ directions, respectively.

$$
\begin{gathered}
\frac{\partial \mathrm{h}}{\partial \mathrm{t}}+\frac{\partial \mathrm{q}_{\mathrm{x}}}{\partial \mathrm{x}}+\frac{\partial \mathrm{q}_{\mathrm{y}}}{\partial \mathrm{y}}=0 \\
\frac{\partial \mathrm{q}_{\mathrm{x}}}{\partial \mathrm{t}}+\frac{\partial \mathrm{q}_{\mathrm{x}} \frac{\mathrm{q}_{\mathrm{x}}}{\mathrm{H}}}{\partial \mathrm{x}}+\frac{\partial \mathrm{q}_{\mathrm{x}} \frac{\mathrm{q}_{\mathrm{y}}}{\mathrm{H}}}{\partial \mathrm{y}}=\sum \mathrm{F}_{\mathrm{x}} \\
\frac{\partial \mathrm{q}_{\mathrm{y}}}{\partial \mathrm{t}}+\frac{\partial \mathrm{q}_{\mathrm{y}} \frac{\mathrm{q}_{\mathrm{x}}}{\mathrm{H}}}{\partial \mathrm{x}}+\frac{\partial \mathrm{q}_{\mathrm{y}} \frac{\mathrm{q}_{\mathrm{y}}}{\mathrm{H}}}{\partial \mathrm{y}}=\sum \mathrm{F}_{\mathrm{y}}
\end{gathered}
$$

$q_{x}$ are $q_{y}$ are the flow rates in the Cartesian coordinates $x$ e $y, t$ is for time, $h$ is the water level, $H$ is for the depth of the water column, and $F_{x}$ and $F_{y}$ are the volume forces in $x$ and $y$ directions. $F_{x}$ and $F_{y}$ are given by Eqs (5) and (6).

$$
\begin{aligned}
& \sum F_{x}=-g H \frac{\partial h}{\partial x}-\frac{n^{2} g|\vec{q}| q_{x}}{H^{1 / 3}}+\frac{1}{\rho}\left(\frac{\partial\left(H \tau_{x x}\right)}{\partial x}\right)+\frac{1}{\rho}\left(\frac{\partial\left(H \tau_{x y}\right)}{\partial y}\right) \\
& +F_{c x}+F_{w x}
\end{aligned}
$$

$$
\sum F_{y}=-g H \frac{\partial h}{\partial y}-\frac{n^{2} g|\vec{q}| q_{y}}{H^{1 / 3}}+\frac{1}{\rho}\left(\frac{\partial\left(H \tau_{y x}\right)}{\partial x}\right)+\frac{1}{\rho}\left(\frac{\partial\left(H \tau_{y y}\right)}{\partial y}\right)
$$$$
+F_{c y}+F_{w y}
$$

where $g$ is the acceleration of gravity; $n$ is the Manning coefficient; $|\vec{q}|$ is the module of the specific flow rate; $\rho$ is the water density that is equal to $998 \mathrm{~kg} / \mathrm{m}^{3}$; $\tau_{i \mathrm{j}}$ is the Reynolds stress tensor;

$$
\tau_{i j}=v\left(\frac{\partial \overline{U_{i}}}{\partial x_{j}}+\frac{\partial \overline{U_{j}}}{\partial x_{i}}\right)
$$

and $v$ is the kinematic viscosity that is equal to $1,3 \times 10^{-6} \mathrm{~m}^{2} / \mathrm{s} . F_{c x}$ and $F_{c y}$ are the Coriolis forces in $x$ and $y$ directions, respectively; and $F_{w x}$ and $F_{w y}$ are the wind forces, in the $x$ and $y$ directions, respectively. The influence of the wind was not taken into account and will be studied in a subsequent stage. The Coriolis effect was neglected due to the position of the domain, near the Equator.

The turbulence model is mixing length $\left(\mathrm{L}_{\mathrm{m}}\right)$ due to Rodi (1993). Where $L_{m}$ is the distance between the wall and a point in the flow from of which the wall itself does not influence more the turbulence. This model assumes a balance between creation and dissipation of energy. In this case, the turbulent viscosity is given by:

$$
v_{t}=L_{m}^{2} \sqrt{2 D_{i j} D_{i j}}
$$

$v_{t}$ is the turbulent viscosity; $D_{i j}$ is the $i j$ components of the deformation tensor, given by:

$$
D_{i j}=\frac{1}{2}\left(\frac{\partial \overline{U_{i}}}{\partial x_{j}}+\frac{\partial \overline{U_{j}}}{\partial x_{i}}\right)
$$

\section{HYDRODYNAMIC MESH}

Figure 5 shows the hydrodynamic mesh with triangular finite elements used in the simulations for Lake Água Preta. The mesh stores all input variables required for the resolution of Saint-Venant equations, as well as the resulting variables for the simulation of the two-dimensional flow $(\mathrm{U}, \mathrm{V}$ and $\mathrm{H})$. For the model considered herein, the input variables are: coordinates $x, y$ and $z$, interpolated via TEM and transferred to the hydrodynamic mesh; the Manning friction coefficient value calculated; and the boundary conditions defined previously.

Hydrodynamic meshes were used in the simulations with the larger edge of the triangles for the finite elements equal to $15.0,10.0$ and $5.0 \mathrm{~m}$. The difference between the errors in the mass balance between the input and output of the domain for the $10.0 \mathrm{~m}$ and $5.0 \mathrm{~m}$ meshes was small, being that the $10.0 \mathrm{~m}$ mesh takes a shorter computational time. Thus, the $10.0 \mathrm{~m}$ mesh (Fig. 5) was used for analyzing the results of the hydrodynamic modeling and morphological Analysis of Lake Água Preta. In that case, the mesh has 33,288 triangles and 68,237 
nodes. The simulations were executed on the Pentium 4-2.8 GHZ.

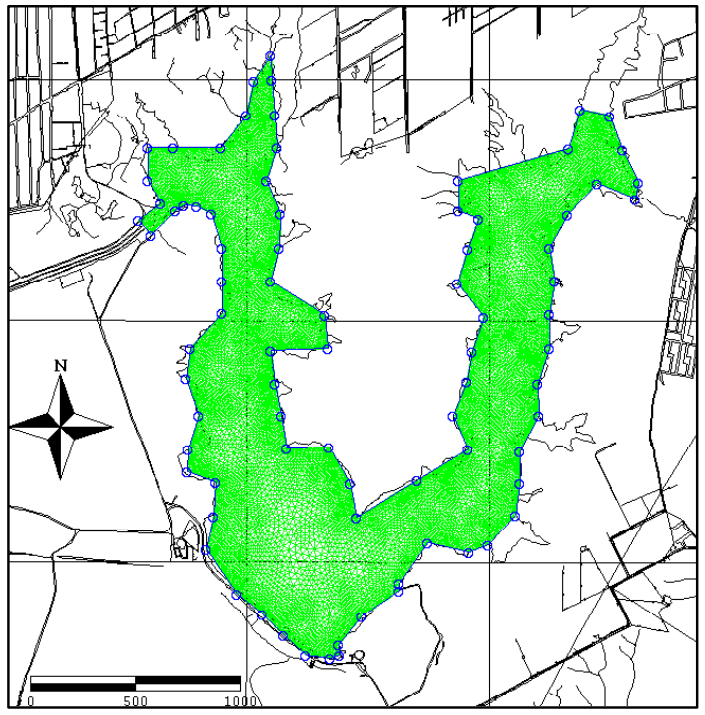

Figure 5. Hydrodynamic mesh of Lake Água Preta.

\section{RESULTS AND DISCUSSION}

\section{INTERPOLATED TEM}

The first result of the application of the Modeleur and Hydrosim is the interpolated TEM by the Finite Element Method, using topography data. Figure 6 presents this information in the form of isosurface.

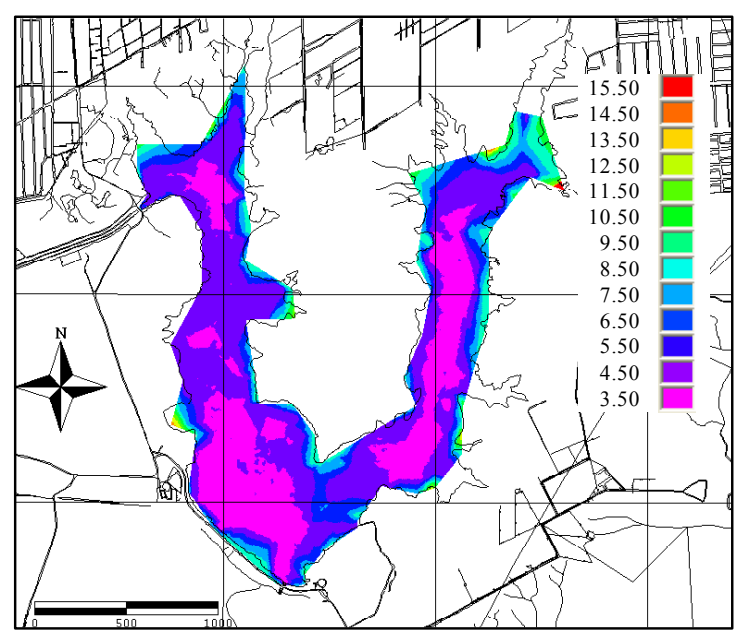

Figure 6. Interpolated TEM's in meters of Lake Água Preta 2009.

By analyzing Fig. 6, it can be observed that the terrain topography is in the range of $3.5 \mathrm{~m}$ to $14.5 \mathrm{~m}$. However, most of the lake has altitudes between 3.5 and $10.0 \mathrm{~m}$, only the north of the lake the altitude reaches $14.5 \mathrm{~m}$. This was observed by Imbiriba Júnior and Da Costa (2003), which noticed that topographical characteristics of the basin wich low altitudes and in softly accidented terrain, typical of the Amazonian region. It originates floodplains in the boundaries of the lake that facilites the transport of domestic and industrial effluents for the lake.

\section{DEPTH}

The depths are simulated by Eq. (10). Being that, in reservoirs such as Lake Água Preta, the water levels have little variation in relation with the water levels of boundary conditions and, thus, the water levels in the lake were equaled to $8.9 \mathrm{~m}$.

$$
\text { Prof }=\text { N.A. }- \text { Topo }
$$

where: Prof is depth (m); N.A. is water level (m); and Topo is the terrain topography $(\mathrm{m})$.

\section{DEPTH 2009}

The isosurfaces of de depth presented in Figure 7, were simulated considering a N.A=8.9 m. In this case, a maximum depth of $5.0 \mathrm{~m}$ was observed for Lake Água Preta.

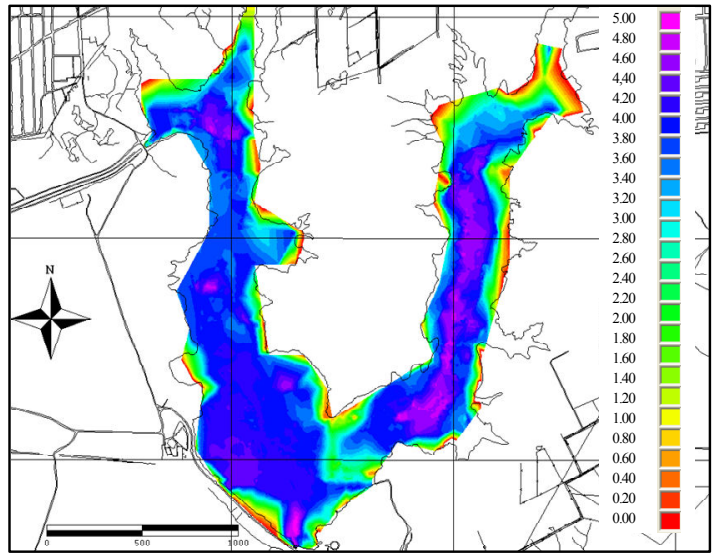

Figure 7. Depth isosurfaces in meters of Lake Água Preta 2009.

\section{VALIDATION OF THE BATHYMETRY OF 2009}

For comparisons with the simulated depths by Sodré (2007), it was applied a N.A. $=7.9 \mathrm{~m}$ in Eq. (8), together with the topography of the TEM of 2009.

Figure 8 shows that the maximum depth found in the lake is $4.40 \mathrm{~m}$, which lies in the southern portion. In the northeast and northwest ends depths ranging from 2.4 to $3.8 \mathrm{~m}$. In the neighborhood of the 
adduction of the river Guamá, the depths range from 0.80 to $1.60 \mathrm{~m}$. These shallow depths are associated with the settling of heavier particles that are deposited near this place, because the water that come from the river Guamá are rich sediments.

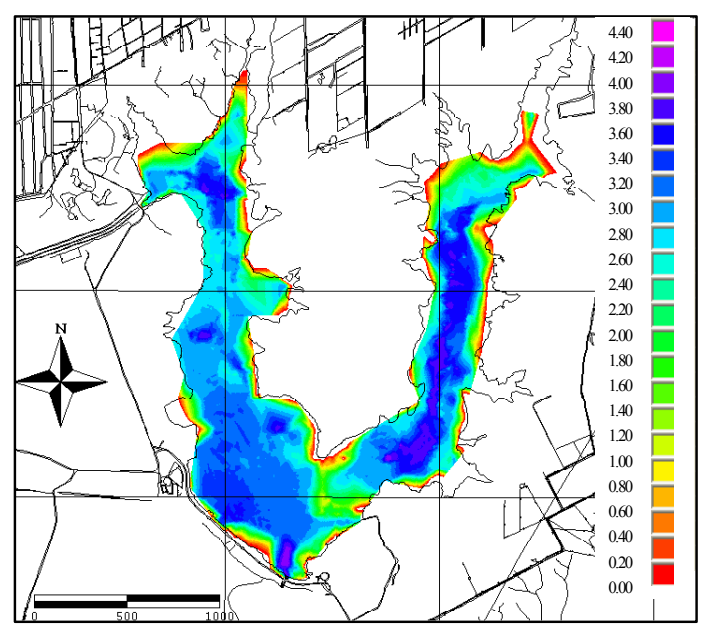

Figure 8. Depth isosurfaces in meters of Lake Água Preta 2009.

Figure 9 shows the simulated depths by Sodré (2007) with measured data in October 2006. In this case, the maximum depth was $4.40 \mathrm{~m}$ in the southern region of the lake. In the region of arrival of the waters of Guamá (Fig. 8) reveals depths range from 0.80 to $1.80 \mathrm{~m}$. In the northeast and northwest edges, were found depths ranging between $2.2 \mathrm{~m}, 3.2 \mathrm{~m}$.

Comparing the simulated depth data for 2009 , with data Sodre (2007), it was found that there was little variation in the depths of the two studies, validating the bathymetry of October 2009 , at least

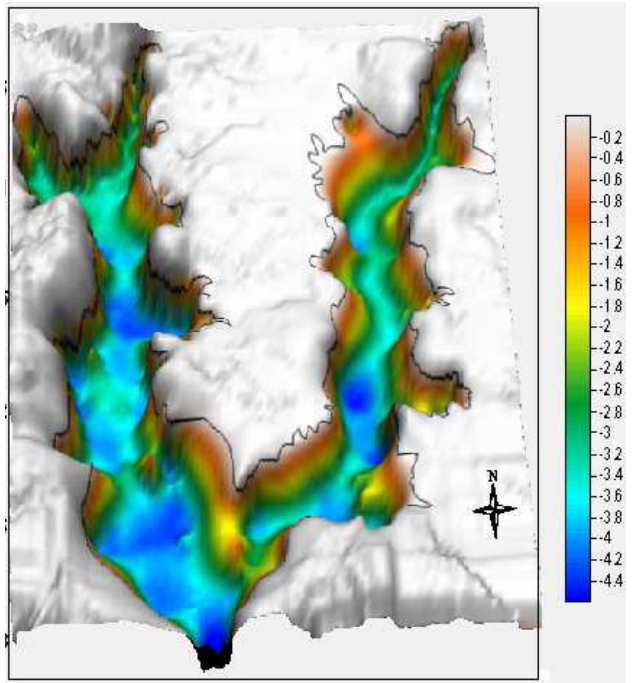

when compared to data available in literature.

Figure 9. Depth isosurfaces in meters of Lake Água Preta 2009. Fonte: Sodré, 2007.

\section{VELOCITY}

Figure 10 presents the simulated velocity field of the Lake Água Preta for 2009. The velocities vary between 0.00 and $0.33 \mathrm{~m} / \mathrm{s}$ between the adduction of the River Guamá and the channel interconnection, while most of the lake velocity is close to zero. The maximum velocity was $0.33 \mathrm{~m} / \mathrm{s}$ at the channel entrance of interconnection, which is explained by the change of section, which passes from a larger to a smaller area, thus explaining the larger velocities.

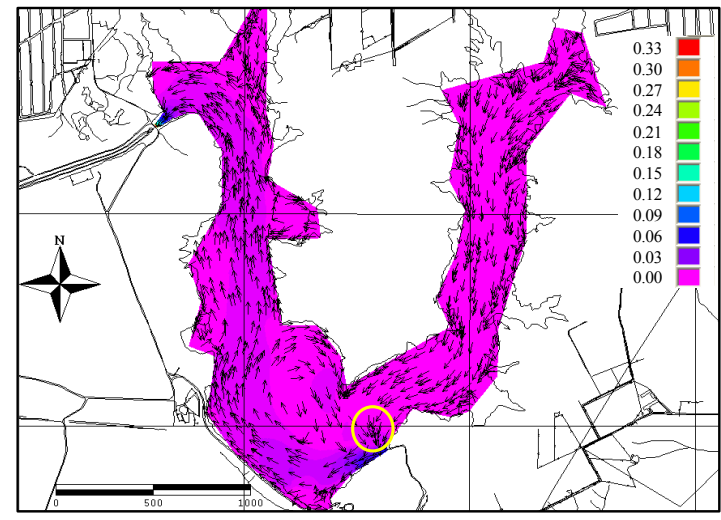

Figure 10. Simulated field for the velocity modules in meters per seconds of Lake Água Preta.

Figure 10 also shows near the adduction (area circled in yellow) a diversion of flow due to a region of lower depths, as shown in Fig. 7. Note also, a recirculation zone in the central portion of the lake. In addition, water flows between the adduction of the river Guamá and the interconnection channel of the Lakes Água Preta e Bolonha (Fig. 1). The flow follows the higher depths shown in Figure. 7.

\section{CONCLUSIONS}

The hydrodynamic modeling of Lake Água Preta, presented in this paper, has added to a better physical understanding of what happens with the flow pattern of Lake Água Preta. Comparison between the raw terrain elevation models from 2009 and those interpolated in the hydrodynamic mesh demonstrated that the interpolated models represent well the terrain being analyzed, thus allowing for using them in depth and velocity simulations for the lake. It was observed for the maximum calculated depth of the lake Água Preta is of $5.0 \mathrm{~m}$.

The simulation result for the outflow pattern of the lake revealed a subtle current with velocities ranging from 0.00 to $0.33 \mathrm{~m} / \mathrm{s}$ between the adduction of the river Guamá and water outlet channel by interconnecting Lakes Água Preta and Bolonha. Regarding the maximum velocities, top velocities reached $0.33 \mathrm{~m} / \mathrm{s}$ and could be found in those regions near the water outlet channel by interconnecting Lakes Água Preta and Bolonha. 
The hydrodynamics Modeling presented in this paper can be used in the foreground, such a hydraulic engineering tool, supporting thus the management of water resources of lakes used as urban water reservoir.

\section{ACKNOWLEDGEMENTS}

The authors wish to thank $\mathrm{CNPq}$ - "Conselho Nacional de Desenvolvimento Científico e Tecnológico", of the Brazilian Ministery for Science and Technology, through the dossiers 350398/2005-4 and 134597/2008-7; SEDECT - "Secretaria de Ciência e Tecnologia", of the State of Pará, through the dossier 001/2006 for the financial support provided, and COSANPA - "Companhia de Saneamento", of State of Pará; and CPRM - "Serviço Geológico do Brasil for the data and technical support.

\section{REFERENCES}

Barros, M. L. C., Sena, M. J. S, Mesquita. A. L. M., Blanco, C. J. C., and Secretan, Y., 2011, Water flow pattern analysis of Guajará Bay - Amazon Estuary - Brazil, Journal of the Brazilian Society of Mechanical Sciences and Engineering, v. 33, p. 7985.

Blanco, C. J. C., Sena, M. J. S., Mesquita, A.L.M., and Secretan, Y., 2009, Application of a 2D shallow water model to analyze the flow and the use of Groins to protect an area of the Amazon River estuary. Revista Ambiente \& Água, v. 4, n. 2, pp. 1020.

Dias, S. F., 1991, Estudo ambiental no Utinga: vida útil do sistema de abastecimento d'água de Belém. Belém. Instituto do Desenvolvimento Econômico-Social do Pará. (in Portuguese)

Heniche, M. A, Secretan, Y., Boudreau, P., and Leclerc, M., 2000. A two-dimensional finite element drying-wetting shallow water model for rivers and stuaries. Advances in Water Resources. v. 23, p. 359372.

Holanda, P. S, Blanco, C. J. C, Cruz, D. O. A, Barp, A. R. B., and Secretan., 2009, Hydrodynamic Modeling of the Lake Água Preta: water sources of the Belém Metropolitan,. In: ANAIS OF XX International Congress of Mechanical Engineering, 15-20 nov., Gramado. 1 CD-ROM.

Holanda, P. S., Blanco, C. J. C., Cruz, D. O. A., Lopes, D. F., Barp, A. R. B., and Secretan, Y., 2010, Sedimentation Modeling of the Lake Água: Water Source of the Belém Metropolitan Area, In: IX ENES - Brazilian Conference on Sediments, Brasília-DF, Brazil. (in Portuguese)

Imbiriba Junior, M., Da Costa, F. R., 2003, Recursos Hídricos: O caso dos mananciais dos lagos Bolonha e Água Preta na Região Metropolitana de Belém, Pará. In: $33^{\mathrm{a}}$ Assembléia Nacional da
ASSEMAE, Santo André. 33 $3^{\mathrm{a}}$ Assembléia Nacional da ASSEMAE. (in Portuguese)

Rodi, W., 1993, Turbulence models and their application in hydraulics: a state of the art review. $3^{\mathrm{a}}$. ed. Balkema. Taylor \& Francis, 104pp.

Secretan, Y., and Leclerc, M., 1998, Modeleur: a 2D hydrodynamic GIS and simulation software. In hyroinformatics-98, Copenhagen, pp. 1-18.

Secretan, Y., and Roy, Y., 2000, Modeleur: User's Guide 1.0a07. 2000 - INRS-Eau, Québec.

Sodré, S. S. V., 2007, Hydrochemistry of the Lakes Bolonha e Água Preta: Water sources of Belém city. Master Thesis in environmental sciences, Earth Sciences Institute, Federal University of Pará, BelémPA, Brazil, 114pp. (in Portuguese)

Received: April 03, 2010

Revised: May 03, 2010

Accepted: June 03, 2010 